Original Articles

\title{
Women who were burned by their husbands or partners*
}

\author{
Mulheres queimadas pelos maridos ou companheiros
}

Mujeres quemadas por los maridos o compañeros

\author{
Normélia Maria Freire Diniz ${ }^{1}$, Regina Lúcia Mendonça Lopes ${ }^{2}$, Adriana Diniz \\ Rodrigues $^{3}$, Daniela Santos de Freitas ${ }^{4}$
}

\begin{abstract}
Objective: To analyze the affect of domestic violence among women who were burned by their husbands or partners. Methods: A quantitative descriptive and exploratory study was used. The sample consisted of 35 young black women who had elementary or high school education. Results: Domestic violence causes women to become sick, which leads to major psychological problems, including depression, posttraumatic stress disorder, and suicidal ideation. Care of these women was focused on their physical injuries. Conclusions: There is a need to enforce public policies regarding domestic violence, and to train health care providers to recognize and provide quality care to victim of domestic violence, which include psychological effects.
\end{abstract}

Keywords: Domestic violence; Burns; Women's health; Family relations

\section{RESUMO}

Objetivo: $\mathrm{O}$ estudo teve como objetivo geral analisar as lesões corporais por queimaduras em mulheres e sua associação com a violência doméstica. Métodos: Utilizou-se o estudo descritivo, exploratório, quantitativo. A população foi constituída por 35 mulheres, em sua maioria jovem, de cor negra e com o $1^{\circ}$ e o $2^{\circ}$ graus de escolaridade. Resultados: A violência causa o adoecimento das mulheres. Suas conseqüências conduzem problemas mentais, inclusive depressão, estresse pós-traumático e tendência ao suicídio. As práticas dos profissionais limitam-se a abordagem clínica. Conclusões: É preciso fortalecer as políticas públicas de atendimento à mulher em situação de violência, sensibilizando os profissionais, que compõem a rede de atendimento a mulheres, para reconhecer a violência, favorecendo a quebra do silêncio que permeia a violência no espaço privado.

Descritores: Violência doméstica; Queimaduras; Saúde da mulher; Relações familiares

\section{RESUMEN}

Objetivo: En este estudio se tuvo como objetivo general analizar las lesiones corporales por quemaduras en mujeres y su asociación con la violencia doméstica. Métodos: Se utilizó el estudio descriptivo, exploratorio, cuantitativo. La población estuvo constituida por 35 mujeres, en su mayoría joven, de color negra y con $1^{\circ}$ y $2^{\circ}$ grado de escolaridad. Resultados: La violencia causa la enfermedad de las mujeres. Sus consecuencias conducen problemas mentales, inclusive depresión, estrés post-traumático y tendencia al suicidio. Las prácticas de los profesionales se limitan al abordaje clínico. Conclusiones: Es preciso fortalecer las políticas públicas de atención a la mujer en situación de violencia, sensibilizando a los profesionales, que componen la red de atención a mujeres, para reconocer la violencia, favoreciendo la quiebra del silencio que presenta la violencia en el espacio privado.

Descriptores: Violencia doméstica; Quemaduras; Salud de la mujer; Relaciones familiares

\footnotetext{
* Study carreid in General Hospital of the State - Secretariat Health of the State of Babia.

Associate Professor at the Babia Federal University (EEUFBA) - College of Nursing, Brazil.

${ }^{2}$ Full Professor at the Babia Federal University (EEUFBA) - College of Nursing, Brazil.

${ }^{3}$ MNS, Nursing in Maternitie Hospital Professor José Maria de Magalhães Netto - Salvador (BA), Brazil.

${ }^{4}$ Academic at the Babia Federal University (EEUFBA) - College of Nursing, Brazil.
} 


\section{INTRODUCTION}

Violent acts against women affect their physical and mental health, as well as their welfare, security, self-esteem, and can also cause depression. Other consequences of violence include infection by sexually transmitted diseases and unwanted pregnancies. Hence, violence is an important social and public health issue.

Studies have shown that domestic violence accounts for initiating traumatic events among women who seek emergency care. Of the women who referred to the emergency care service at a public hospital in the city of Salvador, $45 \%$ reported domestic violence as the reason for their injuries and consequent hospitalization. Regarding the forms of physical violence, beating or pushing represent $64.4 \%$, and burns represent $20 \%{ }^{(1)}$. Another study, performed in a public hospital in Rio de Janeiro, showed that beatings occurred in $70.4 \%$ of the cases, which confirms that physical injury often increases the number of women forwarded to emergency services ${ }^{(2)}$.

Burns are acknowledged as one of the traumas that most impair and disfigure victims, and require long periods of medical care ${ }^{(3)}$. A study performed at the Burn Unit of the Ribeirao Preto Medical School Hospital, showed that adult female patients were burnt in domestic situations $(67 \%)$ or in suicide attempts (33\%). Of the total number of patients who attempted suicide by means of burning agents, $75 \%$ were women. Alcohol was used in all the reported suicide attempts. Women's most affected body parts include: head, neck, anterior and posterior thorax, and upper limbs. Burns of these regions generally occur when the burning agent is thrown on the victim(4). According to this information, women suicide events in the domestic environment could be associated with violence.

Burns are among the most serious traumas, because besides the physical injuries that could lead to death, they cause other psychological and social problems. Moreover, the psychological sequelae due to abuse destroy women's self-esteem, and increase their chances of developing mental disorders, like depression, phobia, tendency to suicide, alcohol and substance use and abuse, and posttraumatic stress disorder ${ }^{(5)}$.

Posttraumatic stress disorder refers to the development of specific symptoms that appear after extreme exposure to a traumatic stressor. It involves direct personal experience of a real or threatening event involving death, injury, or threats to one's physical integrity. This experience can also take place through witnessing or becoming aware about the event ${ }^{(())}$.

Domestic life, rape, and childhood sexual abuse are among the most common causes of posttraumatic stress disorder ${ }^{(7)}$. Hence, the Health Ministry considers this violence-associated disorder a health issue.
There is epidemiologic and social importance regarding violence against women, since it arouses questions that are yet unclear and require further consideration to uncover violence in the field of family relationships and in the domestic environment, which is usually considered a safe place.

In this view, the overall purpose of this study is to evaluate domestic violence as a trigger for women's health problems. The specific purposes are to identify domestic violence as the cause of burns in women; and to identify the repercussions of violence over women's physical and emotional health.

\section{METHODS}

This descriptive, exploratory, quantitative study was performed at the emergency service of a reference burns hospital located in the city of Salvador, Bahia, Brazil.

The study sample was systematically selected and consisted of 35 women with injuries caused by burnings, hospitalized in the Burns Unit. Data collection was performed between January and April 2005, by means of interviews administered using a structured question form. Patient records were also analyzed for additional information.

All ethical and legal aspects were taken into consideration, as per Resolution $\mathrm{N}^{\circ} .196 / 96$ of the National Health Council ${ }^{(8)}$. The project was approved by the Institution Review Board at the Bahia State Health Secretariat. Subjects provided written informed consent regarding their participation in the study, and thus were aware of the study purpose.

In this study, the chosen variables were body injuries caused by burns, and domestic violence were sociodemographic data.

The data were organized and displayed in tables (MS Word and MS Excel), and presented in the form of descriptive percentages. Studies concerning gender issues, domestic violence, burns, and posttraumatic stress disorders were used as the foundation for the analysis.

\section{RESULTS}

Results show that most women were between 21 and 30 years old (42.8\%), which denotes a young population. Regarding ethnicity, the definitions by the Brazilian Institute of Geography and Statistics were followed, which established that "black population" includes black and brown individuals. Hence, $80 \%$ of the interviewed women were black (48.6\% black, and $31.4 \%$ brown).

Regarding educational levels, $14.3 \%$ report being literate, $28.6 \%$ state they have completed the primary education or have incomplete secondary education. Most women are single $(62.9 \%)$, of which $68 \%$ report living 
with their partner.

As to occupation, most women report working outside the home (48.6\%), of which $35.3 \%$ are maids. Regarding independence, $85.7 \%$ stated being financially dependent (51.4\% partially dependent, and 34.3\% totally dependent), of which $76.7 \%$ state their husband/partner help them financially.

In terms of domestic violence, $83 \%$ of the women report having suffered some kind of violence. In $71.2 \%$ of the cases analyzed, the identified aggressors were husband/partner, ex-husband/ex-partner, or father/ mother, which characterizes family violence. The strongest emphasis was on marital violence, which corresponded to $51.2 \%$ of all women.

Regarding body injury, $11.7 \%$ of the burns originated from physical violence; and 8.3\% were hospitalized with burns due to suicide attempts. Therefore, adding suicide attempts and aggressions, $20 \%$ of women illness results from violence. It is worth emphasizing that, in terms of their motives for suicide, $100 \%$ of the women reported that their husband's/partner's violence preceded their suicide attempt. All these women were experiencing the explosion phase, which Ferreira ${ }^{(9)}$ recognizes as a cycle of violence.

In this study, alcohol appeared as the most stated burning agent, reported by women who suffered aggression, attempted suicide, and suffered accidents (75\%, $66.7 \%$, and $57 \%$, respectively).

Considering the scale in the Diagnostic and Statistic Manual of Mental Disorder ${ }^{(6)}$, the study showed that $85.7 \%$ of the abused women experienced concentration difficulty and astonishment. Percentages for those who suffered accidents were $39.3 \%$ and $32.1 \%$, respectively. It should be noticed that over $50 \%$ of abused women report reliving the trauma, suffering from insomnia, feeling guilty, and avoiding any associations with facts that concern the traumatic event; $42.6 \%$ report they feel isolated and $42.6 \%$ state they do not value themselves.

Regarding health care professionals' identification of violence against women, results show that only $20 \%$ address physical aggression.

\section{DISCUSSION}

The sociodemographic variables in this study show that women's financial dependence to their husband/ partner is linked to a historical process denoting the power relation between men and women. Beauvoir ${ }^{(10)}$ states that:

They are women who by virtue of their physiological condition; as far as history is concerned, they have always been subordinated to men: their dependence is not a consequence of an event, or an evolution (...).
The maid profession has always been one of the main female occupations, reflecting gender issues. The fact that this profession is considered feminine would permit them to practice the occupation with more propriety.

The domestic violence incidence observed in this research is in agreement with previous studies ${ }^{(1-2)}$, which show that, in average, $70 \%$ of the interviewed women have a history of violence. These data are essential to understand women's risk of becoming ill.

Hence, violence is a health problem determined by multiple systemic interactions. These interactions have biologic, psychological, and social characters, which are entwined in a network of interactions comprised in human activities. Family living, as a reproducer of culture or violence, as it often occurs, is no longer an environment for learning and education for life; rather, it is transformed into a school that teaches that violence is an "efficacious" form of solving conflicts.

This study shows that husbands/partners were the main aggressors, thus characterizing conjugal violence. Other studies have previously pointed to the aggressor issue, emphasizing that women suffer largely from conjugal violence. In this view, Araújo Gonzáles and Díaz Llanes ${ }^{(11)}$ state that: "Conjugal violence has its roots in three fundamental elements: the social construction of gender, the social legitimization of using violence, and, finally, the double standard moral transmitted in society". In terms of the violence cycle, Porto e Luz ${ }^{(12)}$ state that:

(...) women involved in violent marital relationships constantly experience a cycle of violations that is presented with different functioning dynamics. For some, there is frequent aggression, for others, there are longer intervals; nonetheless, it is repeated for months or years.

For many women, emotional violence is not considered a form of violence, that is, verbal aggressions are so naturalized they are not perceived as aggression. Porto e Luz $^{(12)}$ also state that for some women psychological violence is considered worse than physical violence, and happens more frequently. Hence, psychological violence is referred to as every action or omission that causes or has a view to cause harms to one's self-esteem, identity, or personal development.

Research has shown that a violent relationship can cause psychological changes in women to the point that they attempt suicide as a form of escaping from that situation. These women, prisoners of despair, see suicide as the only reasonable solution. In this view, it is important to stress that when women involved in the web of the cycle of violence come to hospitals with body burns due to a suicide attempt, they are often mistakenly classified as psychiatric patients; and domestic violence, from the gender perspective, is not considered in these women's 
clinical history.

Daskal lists a number of conditions that make women ill, which result (to a larger or smaller amount) from gender discrimination, of which the most significant refers to "participating in a permanent conflict situation, which is not recognized as one"(13).

In terms of the causal agents reported in the research, the result is in line with the study by Rossi et al ${ }^{(4)}$ performed at a Burns Unit at the Ribeirao Preto Medical School Hospital. Alcohol is reported as the main burning agent and the most affected body parts are the thorax, face, and upper limbs.

Physical violence due to burns is considered a major trauma because of the body injuries that affect one's selfimage. Women attribute a negative value to the marks, scars left by violence, and cannot accept the situation. In addition, they state their concern regarding their appearance in terms of the representation that sequelae have on their body image.

According to Schilder ${ }^{(14)}$ (1999), the human body image is the figuration that one forms of their own body in his/her mind. In other words, it is the form that one perceives one's own body. One's body and the respective body image are necessarily part of any individual's life experience with the world. In this sense, women who suffer body injuries not only have a physical mark, but also suffer changes to their self-image; they have to undergo a process of adaptation to their body, according to the way they recognize it and regarding their relationship with the world.

Leonore Walker's theory about the cycle of violence points to women's emotional dependence, who remains connected to a fatality that always makes her go through the same experience. Consequences lead to mental problems, including depression, posttraumatic stress disorder, tendency to suicide, and alcohol and drug abuse.

Ballone's ${ }^{(6)}$ study concerning posttraumatic stress disorder shows that "posttraumatic stress symptoms are typically mist and variable, and initially behave as a state of confusion, characterized by a certain narrowing of one's conscience field and difficulty to concentrate (...)". The study also stresses that the sensation of reliving the trauma causes anguish and intense psychological suffering, leading to social isolation, unsatisfactory professional performance, and life quality deterioration. Hence, women subjected to these violent actions are no longer self-possessed, and consequently lose domination over their being and their freedom. Therefore, it is inferred that domestic violence causes posttraumatic stress disorders in women, which should be considered a health issue.

The Brazilian Health Ministry ${ }^{(15)}$ defines posttraumatic stress as:

... psychological changes that could result from trauma, including the state of shock that occurs immediately after aggression, which could last several hours or days. Another common symptom is panic episode, which can be repeated for long periods. Other symptoms include anxiety, fear and confusion, phobias, insomnia, nightmares, diffidence, feelings of inferiority, failure, insecurity or guilt, low selfesteem, self-destructive behavior - like alcohol and drug abuse -, depression, and suicide attempts.

In terms of health care professionals identifying violence against women, the present study results are in agreement with those of Diniz ${ }^{(1)}$, stating that only 14\% of domestic violence cases were identified by health care professionals. These results are also in line with those of Silva ${ }^{(16)}$, who observed that although some health care professionals noticed violent situations regarding their patients, their work was limited to the clinical approach. Founded on the social construction of gender, health care professionals consider violence a private problem, and blame women for their own suffering, or, yet, consider domestic violence a pathology or match it to the inequality caused by economic issues ${ }^{(17)}$.

\section{CONCLUSIONS}

Results show that most women are between 21 and 30 years old, which characterize a young population.

In terms of ethnicity, $78.8 \% \%$ of the interviewed women were black $(51.5 \%$ black and $27.3 \%$ brown).Regarding educational level, $15.2 \%$ report being literate, $30.3 \%$ state they have completed the primary education or have incomplete secondary education. Results also evidenced that most women are single (63.3\%), of which $71.4 \%$ report living with their partner.

As to occupation, most women report working outside the home $(51.5 \%$ ), of which $35.3 \%$ are maids. Most women reported being financially dependent and stated that their husband/partner helps them financially. The maid profession has always been among the main female occupations, which reflects gender issues.

In terms of violence history, the study showed that $83 \%$ of the women have a history of violence, and the main aggressors are husband/partner, ex-husband/expartner, or father/mother, which totals $71.2 \%$ of the cases and characterizes family violence. The strongest emphasis was on conjugal violence, which corresponded to $51.2 \%$ of all abused women. Hence, it is inferred that domestic violence causes posttraumatic stress disorders in women.

A question that arouses is: what can be done in this regard? The answer perhaps is that public policies regarding assistance provided to women in violence situations should recognize what these women's physical and mental illness means. This would comprise the services composing the assistance network, including health care 
professionals that receive and welcome these women, victims of violence. This action would help women understand and break free from this web that involves and suffocates them. Furthermore, it would permit them to increase their self-esteem, and deal with feelings of fear, anger, pain, and particularly the victim/aggressor relationship.

In addition, this knowledge should be disseminated among health care professionals through specific assistance training programs, since most times these are the first people that women, victims of violence, make contact with.

\section{REFERENCES}

1. Diniz NMF, Rodrigues AD, Bispo TCF, Gomes NP. Violência doméstica: assistência à mulher com lesões corporais. Rev Baiana Enfermagem. 2002; 15(1/2):55-62.

2. Deslandes SF, Gomes R, Silva CMFP. Caracterização dos casos de violência doméstica contra a mulher atendidos em dois hospitais públicos do Rio de Janeiro. Cad Saúde Pública. 2000;16(1):129-37.

3. Werneck GL. Fatores de risco para queimaduras severas na infância. [tese]. Rio de Janeiro: Universidade do Estado do Rio de Janeiro. Instituto de Medicina Social; 1992.

4. Rossi LA, Barruffini RCP, Garcia TR, Chianca TCM. Queimaduras: características dos casos tratados em um hospital escola em Ribeirão Preto (SP), Brasil. Rev Panam Salud Pública [periódico na Internet]. 1998 [citado 2005 Mar 19];4(6):[cerca de 3 p.]. Disponível em: http:/ /www.scielosp .org/ scielo.php?pid=S1020-49891998001200007\&script $=$ sci_arttext

5. Day VP, Telles LEB, Zoratto PH, Azambuja MRF, Machado DA, Silveira MB, et al. Violência doméstica e suas diferentes manifestações. Rev Psiquiatr Rio Gd Sul. 2003;25(Supl 1): 9-21.

6. Ballone GJ. Transtorno por estresse pós-traumático. In: PsiqWeb, Internet [periódico na Internet] 2002 [citado 2004 Abr 15]; [cerca de 6 p.]. Disponível em : http:/ / gballone.sites. uol.com.br/voce/postrauma.html

7. Manero Brito R, Villamil Uriarte R. El síndrome de estrés postraumático y las víctimas de violación. Psicología y Salud [periodico na Internet]. 2003 [citado 2004 Mar 28]. Disponible em: http://www.uv.mx/psicysalud/Psicysalud\%2013_1/ numero_13_1/RManero.html

8. Brasil. Ministério da Saúde. Conselho Nacional da Saúde. Resolução n¹96/96. Pesquisas envolvendo seres humanos. Brasília: Ministério da Saúde; 1996.

9. Ferreira GB. La mujer maltratada: un estudio sobre las mujeres víctimas de la violencia doméstica. 2 nd ed. Buenos Aires: Sudamericana; 1994. 302p.

10. Beauvoir S. O segundo sexo: 1. Fatos e mitos. 2 a ed. Rio de Janeiro: Nova Fronteira; 1980. 309 p.

11. Araujo González R, Díaz Llanes G. Un enfoque teóricometodológico para el estudio de la violencia. Rev Cuba Salud Pública. 2000;26(2):85-90.

12. Porto JRR, Luz AMH. Matizes da violência contra a mulher: conhecendo o fenômeno. Revista Gaúch Enferm. 2004;25(2):207-18.

13. Torres C. La otra mirada de la salud mental [texto en Internet]. Isis Internacional. [citado 2004 br 15]. Disponible en: http:/ / www.isis.cl/temas/salud/reflex4.htm.

14. Schilder P. A imagem do corpo: as energias construtivas da psique. 3a ed. São Paulo: Martins Fontes; 1999.

15. Brasil. Ministério da Saúde. Secretaria de Políticas de Saúde. Prevenção e tratamento dos agravos resultantes da violência sexual contra mulheres e adolescentes: norma técnica. $2 \mathrm{a}$ ed. Brasília: Ministério da Saúde; 2005.

16. Silva IV. Violência contra mulheres: a experiência de usuárias de um serviço de urgência e emergência de Salvador, Bahia, Brasil. Cad Saúde Pública [periódico na Internet]. 2003 [citado 2004 Nov 3]; 19(Supl 2): [cerca de 9 p.]. Disponível em: http: / / www.scielosp.org/scielo.php?script $=$ sci_arttext\&pid= S0102-311X2003000800008.

17. Bispo TCF. Representações sociais de profissionais de saúde acerca da assistência à mulher em situação de violência conjugal [tese] Salvador (BA): Escola de Enfermagem da Universidade Federal da Bahia; 2002. $103 f$. 